\title{
Assessment of Soil Quality of Babhalgaon Village of Latur District for Soil Health and Land Resource Management by using Remote Sensing and GIS Techniques
}

\author{
A. D. Nawkhare, P. H. Vaidya, M. K. Ghode* and N. S. Titirmare \\ Department of Soil Science and Agricultural Chemistry, College of Agriculture, Latur, India \\ *Corresponding author
}

\section{A B S T R A C T}

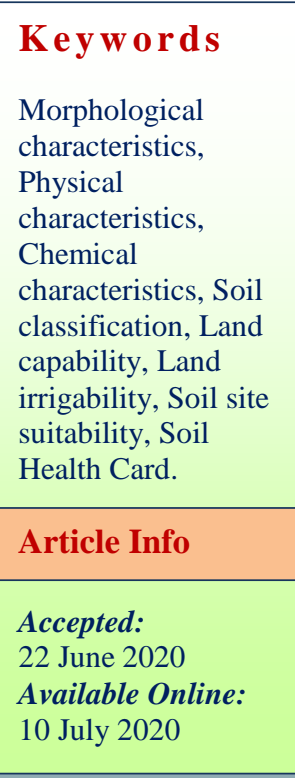

The soils of Babhalgaon village shallow to very deep, black (10 YR 2.5/1) to light gray (10YR 7/2) in colour, granular to angular blocky in structure, sandy to clay in texture, nonsticky non-plastic to very sticky very plastic in nature. The bulk density of soils varied from 1.42 to $1.79 \mathrm{Mg} \mathrm{m}^{-3}$. The hydraulic conductivity and PAWC of soils varied from 2.40 to $29.25 \mathrm{~cm} \mathrm{hr}^{-1}$ and 76.09 to 480.40 per cent respectively. The soils are slightly to strongly alkaline in nature and electrical conductivity is $<1.0 \mathrm{dSm}^{-1}$. The organic carbon content of the soils was low to moderate $(0.21$ to $0.75 \%)$ and calcium carbonate content varied from 6.4 to 16.6 per cent indicated that the soils were calcareous in nature. Low to

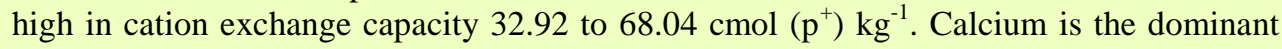
cation followed by magnesium, sodium and potassium in all profiles. The base saturation per cent varied from 78.18 to 99.83 per cent. Taxonomically these soils classified as Typic Ustorthents, Typic Haplustepts and Typic Haplusterts. As per land capability classification the soils of Babhalgaon village were grouped into major capability classes IIIs, IVs and VIs. The land irrigability classes are grouped under 2s and 3s. As per FAO 1983 the soil site suitability, Typic Haplusterts $\left(\mathrm{P}_{1}\right)$ are highly suitable $(\mathrm{S} 1)$, Typic Haplustepts $\left(\mathrm{P}_{2}, \mathrm{P}_{3}\right.$ and $\left.\mathrm{P}_{4}\right)$ moderately suitable (S2) and Typic Ustorthents $\left(\mathrm{P}_{5}\right)$ are marginally suitable (S3) for soybean and pigeon pea crops. The physical properties viz. texture, structure, soil depth, coarse fragments and PAWC various with soil type and was found adversely effect the sustainable yield of commonly grown crop. This is suggested that the soil type and soil quality parameter viz. soil depth, texture, structure, coarse fragments and PAWC should include in the present existing twelve parameter of soil health card and also the to suggest soil site suitability with site specific soil management for sustaining soil use and doubling farmer income.

\section{Introduction}

Soil resources inventory is one of the most important tools for land users and planners for getting information about soil resource for land use and planning, management of soil and getting sustainable production. Soil resource inventory provide knowledge about the genesis classification, capability, suitability, helps to solve the problems related with sustainable production. The value of soil resource inventory for increasing food production and conservation of natural resources has been receiving significant 
importance not only for soil resource data base generated but also its quality (Eswaran and Gathrie, 1982). The importance of soil survey and mapping for preparing an inventory of region, the soil properties are used for evaluation of soil for the different crops. The capability of soil to produce safe and nutritious crop in sustained manner over the long run, and to enhance Human and Animal Health without impairing the natural resource base or adversely affecting the environment. The SHC helps the farmers as the farmers get a well monitored report about the soil and they are guided by the experts to improve soil health. It also helps the farmers to get crop wise recommendations of nutrients and fertilizers required in each type of soil.

\section{Materials and Methods}

Geographically, the Babhalgaon village is located between $76^{\circ} 37^{\prime} 52^{\prime}$ ' E longitudes and $18^{\circ} 23^{\prime} 11$ ' $\mathrm{N}$ latitudes in Babhalgaon village of Latur Tahsil in Latur district, Maharashtra State, India. It belongs to Marathwada region. It is Located Six (6) km away from Latur city (EAST) form district headquarters Latur. The total geographical area of Babhalgaon village in Latur district is 1667.25 ha. The study area falls in the SOI topo sheet no. E 43K11 on 1:50,000 scale. The area is covered by the basaltic lava - flows. Same layer of the lavaflows are hard and compact while other are soft. The general elevation of the area ranges from 620 to $660 \mathrm{~m}$ above mean sea level (MSL). The area is associated with very gently sloping (1-3\%), and gently sloping (3$8 \%$ ) lands. The drainage is, essentially, dendritic in nature.

The climate of the study area was characterized by hot sub-humid and has good distribution of rains during the monsoon season. The climate of the area is hot, dry and sub- humid with annual rainfall of $794 \mathrm{~mm}$ at which nearly 85 per cent is received during
June to September. The mean maximum and minimum temperature are $32.7^{\circ} \mathrm{C}$ and $18.1^{\circ} \mathrm{C}$ respectively. April and May have high temperature $\left(38.8^{0} \mathrm{C}\right.$ and $39.4^{\circ} \mathrm{C}$ mean temperature), December and January coolest month $\left(29.3^{\circ} \mathrm{C}\right.$ and $30.41^{\circ} \mathrm{C}$ mean temperature). The length of growing period 149 days and humid period 104 days soils has Ustic moisture regime and Hyperthermic temperature regime. The most of the area is under Cultivation of pulse crop. Soybean (Glycine max), Pigeonpea (Cajanus Cajan), sorghum (Sorghum bicolar) and sugarcane (Saccharum officinarum) in kharif season where as sorghum (Sorghum bicolar), wheat (Triticum austivum) and gram (Cicer arietinum) in the Rabi season.

Digital data of Landsat-VIII with bands 2, 3 and 4 (2018) was used in the present study. The standard false colour composite (FCC) was generated with the combination of green, red, blue and infrared bands. Survey of India (SOI) toposheet No. E 43K11 (1:50,000 scale) was used to collect topographic and location information. The toposheet was used to prepare base map for different landforms, generation of slope and drainage for planning the traverse route for ground truth collection. The methodology followed for the interpretation of the Landsat-VIII data is essentially the standard visual interpretation technique based on the tone, texture, pattern, shape, size, association etc. The other ancillary data such as toposheet and other available information (reports, maps etc.) were used for preparation of Screen digitization was done to prepare various maps. Using the village maps (prepared from toposheet and satellite data), the area was traversed to verify different landform units and present land use classes. Soil profiles were exposed in each physiographic unit studied for Morphological properties Soil Survey Staff (1975). Horizon-wise soil samples were collected from representive 
pedons and analysed physical, chemical and biological properties following standard procedure (Jackson, 1979, Piper 1966, Gardner et al., 1984), (Richards 1954, Lindsay and Norvell 1978) Subba Rao, (1988).

There are several methods available for qualitative and quantitative evaluation. Among the various methods, the land capability classification (Klingebiel and Montgomery, 1961), land irrigability classification (AIS \& LUS, 1971), and land suitability classification (NBSS \& LUP, 1994 and FAO, 1983) were used for evaluating the suitability of different mapping units for soybean and pigeon pea.

\section{Results and Discussion}

\section{Land use/ land cover}

Based on tone, texture and the pattern the land use/land cover identified in Babhalgaon village of latur district categories such as crop land, fallow land, pond / waterbody and Habitation. The crop land exhibits light's green with diffuse checkerboard pattern on satellite data and occupies an area of 1522.29 ha representing 91.31 per cent of the total geographic area (TGA) of the Babhalgaon village. Fallow land mainly occurs on very gently sloping exhibits purple colour, bold checker board pattern on Landsat-8 (Jan 2018) The Fallow Land occupies an area of 39.76 ha representing 2.38 per cent of the total geographic area (TGA) of the Babhalgaon village. The water body exhibits dark blue with smooth texture on the satellite data and covers an area of 0.44 ha representing 0.03 per cent of the total geographical area of the Babhalgaon village. The Habitation exhibits brown with colour on the satellite data and covers an area of 104.75 ha representing 6.28 per cent of the total geographical area of the Babhalgaon village.

\section{Slope}

Based on contour information available in toposheet, two slope classes viz. nearly level to level $(0-1 \%)$, very gently sloping (1-3\%).

\section{Morphological Characteristics}

Morphological properties of soil indicated (Table 1) Soil depth of study area varied from 30 to $82 \mathrm{~cm}$ which is correspond to shallow to moderately deep. The soil depth in Typic Haplusterts $\left(\mathrm{P}_{1}\right)$ was moderately deep $(82 \mathrm{~cm})$ and Typic Haplustepts $\left(\mathrm{P}_{2}, \mathrm{P}_{3}, \mathrm{P}_{4}\right)$ was (22 to 50) $\mathrm{cm}$ shallow to moderately shallow to moderately deep. Soil depth is an important factor in the crop production which influence crop yield in general, increases in yield with increases in soil depth (De La Rosa 1981). The soil colour of study area are most soils of the study area were black (10 YR 2.5/1) to dark brown (10 YR 3/3) in colour. The pedon $\mathrm{P}_{5}$ (Typic Ustorthents) soils colour varies from 10 YR $3 / 2$ to $10 Y R 7 / 2$ corresponds to the very dark grayish brown to light gray. The pedon $\mathrm{P}_{2}$, $\mathrm{P}_{3}$ and $\mathrm{P}_{4}$ (Typic Haplustepts) soils colour varies from 10 YR 3/1 to 10YR 6/6 corresponds to the very dark grey to Yellowish in colour. The pedon $\mathrm{P}_{1}$ (Typic Haplusterts) soils colour varies from black (10 YR 2.5/1) to very dark grayish brown (10YR 3/2). The soils have structure varies from, medium moderate, sub angular blocky \& medium moderate angular blocky structure in pedon $\mathrm{P}_{1}$ (Typic Haplusterts) showed well- developed intersecting slickenside and wedge shaped structural aggregates (Plate4.2). This may be due to swell shrink properties of Vertisols in such soils resulting in the development of slickenside's (Ahmad 1989).In Typic Haplustepts $\left(\mathrm{P}_{2}, \mathrm{P}_{3}\right.$ and $\left.\mathrm{P}_{4}\right)$ soils structure varies from medium weak sub angular blocky to medium moderate sub angular blocky to granular soils structure. In Typic Ustorthents $\left(\mathrm{P}_{5}\right)$ soils structure varies from medium weak, sub angular blocky to granular soils structure. 
Consistency from table 4.3 shows that in pedon $\mathrm{P}_{2}, \mathrm{P}_{3}$ and $\mathrm{P}_{4}$ (Typic Haplustepts) soil consistency varies from loose, friable,non sticky, non-plastic to hard, firm, very sticky, very plastic in wet condition. While the pedon $\mathrm{P}_{1}$ (Typic Haplusterts) soils consistency varies from slightly hard, extremely hard, firm very sticky, very plastic in wet condition and $\mathrm{P}_{5}$ (Typic Ustorthents) soil consistency varies from slightly friable, non-plastic, very sticky to very plastic in wet condition.

\section{Physical characteristics}

Physical properties of soils were presented in table 2. Indicated that the coarse fragment in soils was varies from 6.18 to 21.38 per cent. The soil texture of sample $\mathrm{P}_{1}, \mathrm{P}_{2}, \mathrm{P}_{3}, \mathrm{P}_{4}$ and $\mathrm{P}_{5}$ was clay to sandy in nature. The clay content varied from 6.18 to 21.38 per cent. The soil developed on lower topographic position showed higher clay content as compared to soil developed on lower topographic position showed higher clay content as compare to soil developed on higher topographic position, topography and slope were found to affect the particle size distribution. The bulk density of soils of Babhalgaon village of Latur district varied from 1.42 to $1.79 \mathrm{Mg} \mathrm{m}^{-3}$. The saturated hydraulic conductivity of the study area varies from 2.40 to $29.25 \mathrm{~cm} \mathrm{hr}^{-1}$.This variation attributed to textural difference.

From the data (Table 4.4), it is observed that the texture of all surface samples in the study area was silty, clay in nature. The plant available water capacity of the soils varied from 76.09 to $480.40 \mathrm{~mm}$. However, of soil found to increase with depth in soil. Gardner et al., (1984) that the plant available water capacity is limited by rooting depth have recorded it. The capacity of soil to store moisture for plant use is largely a function their clay content, depth of soil and mineralogy of soil. The correlation of yield with PAWC ( $\mathrm{r}=0.853184)$ and clay content with PAWC $(r=0.557605)$ were positive correlated obtained. This suggests that the soil depth, texture and PAWC are inter-related to each other and in turn control the crop yield.

\section{Chemical characteristics}

The chemical properties of soils presented in table indicated that the soils are slightly to strongly alkaline in nature with $\mathrm{pH}$ ranged from 7.17 to 8.91 . The electrical conductivity of soil is varies from 0.15 to $0.39 \mathrm{dSm}^{-1}$. Which is well within safe limit of electrical conductivity range, designated for normal soil (Richards, 1954) and all soils comes under non-saline class. The EC value of murrum layer as relatively less as compared to surface layer The organic carbon content of 0.21 to 0.75 per cent. The organic carbon content is low in murrum layer as compared to the over lying horizons \& found decrease with depth. The $\mathrm{CaCO}_{3}$ content in the soil varied from 6.4 to 16.6 per cent.

High calcium carbonate affects the physical and chemical properties of soil and may prevent the root penetration (Sys1985).The cation exchange capacity of soil varied from 32.92 to $68.04 \mathrm{cmol}\left(\mathrm{p}^{+}\right) \mathrm{kg}^{-1}$ The high CEC is attributed to the high amount of clay. The relationship of cation exchange capacity and clay content in soil found to be positively correlated $(r=0.840759)$ and which was increased with increasing clay content in soil.

\section{Soil classification}

Based on field morphology and laboratory characterization the soils on various landforms have been classified according to U.S. comprehensive system of soil classification (Soil Survey Staff 1994 \& 2006) and presented in (Table 4.9). The dominant soils of the study area belonging to three order viz. Inceptisols, Vertisols \& Entisol at Babhalgaon village of Latur district. 
The pedon $\mathrm{P}_{2}, \mathrm{P}_{3}$ and $\mathrm{P}_{4}$ possess ochric epipedons followed by cambic subsurface diagnostic horizons and hence, grouped under Inceptisols. Due to ustic moisture regime, these pedons qualify for ustepts suborder. These pedons do not have duripan horizon and hence are classified under Haplustepts great group. At subgroup level these soil classified as Typic Haplustepts. These soils were deep to very deep, black colored, clayey (>30 \%) and characterized by deep and wide cracks, well developed slickenside and pressure faces. Thus these soils were classified under the order Vertisols and the subgroup level Typic Haplusterts and were observed at nearly level landform pedon $\mathrm{P}_{1}$. The soil developed on moderately sloping nearly level plain at elevated area of the Babhalgaon village of Latur district $\left(\mathrm{P}_{5}\right)$ were lack of diagnostic subsurface horizons. They qualify for the order Entisols and due to presence of Ustic moisture regime the soils are grouped into Ustorthents. At subgroup level, these soils classified as Typic Ustorthents because these soils do not key out for other subgroup.

\section{Land evaluation}

Land evaluation is the process of assessing the potential of land for alternative uses. There are several methods available for evaluating the land both for qualitative and quantitative evaluation. Among the various methods, the land capability classification (Klingebiel and Montgomery1961), land irrigability classification (AIS \& LUS, 1971), and land suitability classification (FAO, 1983) were used.

The land capability classification is a broad grouping of soils based on their limitations and is designed to emphasize the hazards in different kinds of soils. Land suited for cultivation is grouped in class $I$ to class $I V$ according to the degree of limitations. Lands in class $V$ to class VII are suited for silviculture, pasture. Class VIII land is neither suited to agriculture nor forestry but suitable for recreational use.

Land capability classes are divided into subclasses that represent Four kinds of limitation are recognized at subclass level, 'e' for slope, water or wind erosion, ' $w$ ' for drainage problems, wetness or overflow, 's' for soil limitations affecting the plant growth and ' $c$ ' for limitation due to climate.

As per the land capability classification the soil of Babhalgaon are grouped in to capability classes (IIIs, IVs, VIs pond/Waterbody and Habitation) and total Geographical area viz. comprising 18.73, 56.21, 18.73, 0.03, and 6.28 per cent area, respectively.

\section{Land irrigability classification}

Land irrigability classification facilitates grouping of soils into different classes of suitability along with their sub classes based on dominant limitation imposing factors. It is an interpretative grouping based on soil and land characteristics, which indicate relative suitability of land for irrigation as well as predicted behavior of soils under irrigation. The irrigability classification is a combined effect of soil and land Characteristics. Factors considered while grouping soils under different irrigability classes are slope, erosion, texture, depth, drainage, salinity, alkalinity, permeability, etc. The results of different soil mapping units of Babhalgaon village evaluated for their suitability for irrigation has been presented in table 4.26 and the map is shown in (fig.4.31) the soils are grouped under land irrigability subclasses $2 \mathrm{~s}$ and $3 \mathrm{~s}$ comprising $18.73 \%$ and $74.95 \%$ area, Pond/ Water body $0.03 \%$ and $6.28 \%$ area Habitation respectively. 
Table.1 Morphological properties of soil Babhalgaon village of Latur district in Marathwada region

\begin{tabular}{|c|c|c|c|c|c|c|c|c|c|}
\hline Horizon & $\begin{array}{c}\text { Depth } \\
\text { (cm) }\end{array}$ & $\begin{array}{c}\text { Boundar } \\
\mathbf{y}\end{array}$ & $\begin{array}{l}\text { Matrix } \\
\text { Colour }\end{array}$ & Texture & $\begin{array}{c}\text { Structur } \\
\mathrm{e}\end{array}$ & Consistency & Pores & Roots & Effervescence \\
\hline \multicolumn{10}{|c|}{ Pedon 1 - Shriram Mukundrao Deshmukh Babhalgaon Dist.-Latur (Typic Haplusterts) } \\
\hline Ap & $0-18$ & Cs & 10 YR 3/1 & $\mathrm{cl}$ & m2sbk & h, fr, ss,sp & vfm,fm & $\begin{array}{c}\text { vfm,f } \\
\mathrm{m}\end{array}$ & es \\
\hline $\mathbf{B w}_{1}$ & $18-36$ & Cs & $10 \mathrm{YR} 3 / 2$ & $\mathrm{cl}$ & $\mathrm{m} 3 \mathrm{sbk}$ & h, fi, ss,sp & vfm,fm & $\begin{array}{l}\text { vfm, } \\
\text { ff }\end{array}$ & es \\
\hline $\mathbf{B w}_{2}$ & $36-53$ & Cs & $10 \mathrm{YR} 3 / 2$ & $\mathrm{cl}$ & $\mathrm{m} 3 \mathrm{sbk}$ & h, fi, vs, vp & $\mathrm{vfm}, \mathrm{fm}$ & $\begin{array}{l}\text { vfm, } \\
\text { ff }\end{array}$ & es \\
\hline Bss $_{1}$ & $53-66$ & $\mathrm{Cs}$ & $10 \mathrm{YR} 3 / 2$ & $\mathrm{cl}$ & m3abk & h, fi, vs, vp & vfm,ff & $\mathrm{fm}, \mathrm{ff}$ & ev \\
\hline $\mathbf{B s s}_{2}$ & $66-82$ & Cs & $\begin{array}{c}10 \mathrm{YR} \\
2.5 / 1\end{array}$ & $\mathrm{cl}$ & m3abk & eh,fi,vs,vp & fm,ff & fm, ff & ev \\
\hline $\mathbf{B s s}_{3}$ & $82-150$ & Cs & $\begin{array}{c}10 \mathrm{YR} \\
2.5 / 1\end{array}$ & $\mathrm{cl}$ & m3abk & eh,fi,vs,vp & $\mathrm{fm}, \mathrm{ff}$ & $\mathrm{fm}, \mathrm{ff}$ & ev \\
\hline \multicolumn{10}{|c|}{ Pedon 2 - Nabi Ismail Pathan Babhalgaon Dist.-Latur (Typic Haplustepts) } \\
\hline Ap & $0-22$ & Cs & $10 \mathrm{YR} 3 / 2$ & $\mathrm{cl}$ & m1sbk & sh,fr,ss, sp & $\mathrm{vfm}, \mathrm{fm}, \mathrm{fm}$ & $\mathrm{fm}, \mathrm{fm}$ & e \\
\hline $\mathbf{B w}_{1}$ & $22-43$ & Cs & $10 \mathrm{YR} 3 / 1$ & $\mathrm{cl}$ & $\mathrm{m} 2 \mathrm{sbk}$ & sh, fr, ss, sp & $\mathrm{vfm}, \mathrm{fm}$ & $\begin{array}{l}\mathrm{vfm}, \\
\mathrm{fm}\end{array}$ & es \\
\hline $\mathrm{Cr}$ & $43-60$ & -- & 10 YR 6/3 & $\mathrm{s}$ & gr & vh, ns, np & $\mathrm{vfm}, \mathrm{fm}, \mathrm{mm}$ & $\mathrm{ff}, \mathrm{cf}$ & ev \\
\hline \multicolumn{10}{|c|}{ Pedon 3 - Das Joytiram Gaykwad Babhalgaon Dist.-Latur (Typic Haplustepts) } \\
\hline Ap & $0-18$ & Cs & $10 \mathrm{YR} 3 / 2$ & $\mathrm{cl}$ & m1sbk & $1, \mathrm{fr}, \mathrm{ss}, \mathrm{sp}$ & $\mathrm{vfm}, \mathrm{fm}$ & vf,fm, & e \\
\hline $\mathbf{B w}_{1}$ & $18-32$ & $\mathrm{Cw}$ & $10 \mathrm{YR} 3 / 3$ & $\mathrm{cl}$ & m2sbk & $h$, fr, ss, sp & vfm,fm & vf,fm & e \\
\hline $\mathrm{Cr}$ & $32-50$ & -- & 10 YR 6/6 & $\mathrm{s}$ & gr & h, fi, ns, np & $\mathrm{fm}, \mathrm{cf}$ & $\mathrm{ff}, \mathrm{cf}$ & es \\
\hline \multicolumn{10}{|c|}{ Pedon 4 - Santosh Namdev Bhange Babhalgaon Dist.-Latur(Typic Haplustepts) } \\
\hline Ap & $0-25$ & $\mathrm{Ca}$ & 10 YR 3/1 & $\mathrm{cl}$ & m1sbk & lfr,ss, sp & vf,fm, & vffm, & e \\
\hline $\mathbf{B w}_{1}$ & $25-40$ & $\mathrm{Ca}$ & $10 \mathrm{YR} 3 / 2$ & $\mathrm{cl}$ & m1sbk & sh,fr.ss,sp & $\mathrm{fm}, \mathrm{ff}$ & $\begin{array}{l}\mathrm{vf}, \\
\mathrm{mm}\end{array}$ & e \\
\hline $\mathrm{Cr}$ & $40-54$ & -- & $10 \mathrm{YR} 3 / 2$ & $\mathrm{~s}$ & gr & vh, eh,ns, np & $\mathrm{ff}, \mathrm{cf}$ & $\mathrm{ff}, \mathrm{cf}$ & es \\
\hline \multicolumn{10}{|c|}{ Pedon 5 - Shalik Deshmukh Babhalgaon Dist.-Latur(Typic Ustorthents) } \\
\hline Ap & $0-28$ & $\mathrm{Cs}$ & $10 \mathrm{YR} 3 / 2$ & $\mathrm{cl}$ & $\mathrm{m} 1 \mathrm{sbk}$ & $\mathrm{s}, \mathrm{fr}, \mathrm{ss}, \mathrm{sp}$ & vfm,fm, & $\begin{array}{c}\mathrm{vfm}, \mathrm{f} \\
\mathrm{m}\end{array}$ & e \\
\hline $\mathrm{Cr}$ & 28-60 & -- & 10 YR 7/2 & cl & gr & s,fr.ns,np & vfm & $\begin{array}{l}\text { vff, } \\
\text { fm }\end{array}$ & ev \\
\hline
\end{tabular}


Table.2 Physical properties of Babhalgaon village of Latur district of Marathwada region of Maharashtra

\begin{tabular}{|c|c|c|c|c|c|c|c|c|c|c|c|}
\hline \multirow[t]{2}{*}{ Horizon } & \multirow{2}{*}{$\begin{array}{l}\text { Depth } \\
\text { (cm) }\end{array}$} & \multirow{2}{*}{$\begin{array}{c}\text { Coarse } \\
\text { fragment } \\
(\%)\end{array}$} & \multirow[t]{2}{*}{$\begin{array}{c}\text { BD } \\
\left(\mathrm{Mgm}^{-3}\right)\end{array}$} & \multirow[t]{2}{*}{$\begin{array}{c}\mathrm{HC} \\
\left(\mathrm{cm} \mathrm{hr}^{-1}\right)\end{array}$} & \multicolumn{3}{|c|}{ Particle size analysis (\%) } & \multicolumn{2}{|c|}{$\begin{array}{c}\text { Moisture retention } \\
(\%)\end{array}$} & \multirow[t]{2}{*}{$\begin{array}{c}\mathrm{AWC} \\
(\%)\end{array}$} & \multirow[t]{2}{*}{$\begin{array}{c}\text { PAWC } \\
(\%)\end{array}$} \\
\hline & & & & & Sand & Silt & Clay & $33 \mathrm{kPa}$ & $1500 \mathrm{kPa}$ & & \\
\hline \multicolumn{12}{|c|}{ Pedon 1 - Shriram Mukundrao Deshmukh Babhalgaon Dist.-Latur (Typic Haplusterts) } \\
\hline Ap & $0-18$ & 6.47 & 1.54 & 4.13 & 4.02 & 27.06 & 68.69 & 45.72 & 28.35 & 17.37 & \multirow{6}{*}{480.40} \\
\hline $\mathbf{B w}_{1}$ & $18-36$ & 6.18 & 1.69 & 5.63 & 3.69 & 33.27 & 63.01 & 47.06 & 27.40 & 19.66 & \\
\hline $\mathbf{B w}_{2}$ & $36-53$ & 6.48 & 1.54 & 2.40 & 3.47 & 42.76 & 53.47 & 26.81 & 13.74 & 13.07 & \\
\hline Bss $_{1}$ & 53-66 & 7.76 & 1.66 & 3.03 & 3.11 & 35.45 & 61.33 & 36.71 & 19.62 & 17.09 & \\
\hline $\mathbf{B s s}_{2}$ & $66-82$ & 7.52 & 1.42 & 3.62 & 2.92 & 31.24 & 65.68 & 43.06 & 22.17 & 20.89 & \\
\hline $\mathbf{B s s}_{3}$ & $82-150$ & 8.02 & 1.65 & 4.26 & 2.69 & 25.98 & 71.02 & 46.09 & 23.16 & 22.93 & \\
\hline \multicolumn{11}{|c|}{ Pedon 2 - Nabi Ismail Pathan Babhalgaon Dist.-Latur (Typic Haplustepts) } & \multirow{4}{*}{101.59} \\
\hline Ap & $0-22$ & 6.82 & 1.43 & 10.28 & 09.23 & 26.24 & 64.03 & 43.01 & 28.04 & 14.07 & \\
\hline $\mathbf{B w}_{1}$ & $22-43$ & 7.98 & 1.47 & 13.93 & 11.47 & 20.09 & 68.09 & 45.42 & 28.64 & 16.78 & \\
\hline $\mathbf{C r}$ & $43-60$ & 13.99 & - & 29.25 & 13.21 & 34.18 & 52.01 & 25.47 & 13.17 & 12.03 & \\
\hline \multicolumn{11}{|c|}{ Pedon 3-Das Joytiram Gaykwad Babhalgaon Dist.-Latur (Typic Haplustepts) } & \multirow{4}{*}{76.09} \\
\hline Ap & $0-18$ & 18.18 & 1.71 & 2.68 & 8.60 & 24.07 & 67.03 & 44.09 & 28.18 & 15.91 & \\
\hline $\mathbf{B w}_{1}$ & $18-32$ & 20.83 & 1.45 & 9.44 & 12.56 & 26.23 & 61.01 & 36.28 & 19.34 & 16.94 & \\
\hline $\mathrm{Cr}$ & $32-50$ & 21.38 & - & 16.66 & 13.87 & 33.89 & 52.07 & 25.89 & 13.52 & 12.37 & \\
\hline \multicolumn{11}{|c|}{ Pedon 4- Santosh Namdev Bhange Babhalgaon Dist.-Latur (Typic Haplustepts) } & \multirow{4}{*}{144.05} \\
\hline Ap & $0-25$ & 9.38 & 1.46 & 7.79 & 7.39 & 36.72 & 63.09 & 45.05 & 28.61 & 16.44 & \\
\hline $\mathbf{B w}_{\mathbf{1}}$ & $25-40$ & 11.41 & 1.56 & 10.90 & 10.64 & 27.13 & 62.14 & 36.73 & 19.68 & 17.05 & \\
\hline $\mathrm{Cr}$ & $40-54$ & 19.29 & 1.74 & 18.36 & 14.04 & 29.84 & 56.03 & 42.13 & 23.07 & 18.43 & \\
\hline \multicolumn{12}{|c|}{ Pedon 5- Shalik Deshmukh Babhalgaon Dist.-Latur(Typic Ustorthents) } \\
\hline Ap & $0-28$ & 7.50 & 1.79 & 2.54 & 4.37 & 61.01 & 34.62 & 20.08 & 13.02 & 7.06 & \multirow[b]{2}{*}{79.01} \\
\hline $\mathrm{Cr}$ & $28-60$ & 18.02 & 1.46 & 8.45 & 5.60 & 61.48 & 32.92 & 18.04 & 9.07 & 8.07 & \\
\hline
\end{tabular}


Table.3 Chemical properties of soil Babhalgaon village of Latur district in Marathwada region

\begin{tabular}{|c|c|c|c|c|c|c|c|c|c|c|c|c|}
\hline \multirow{2}{*}{$\begin{array}{l}\text { Horiz } \\
\text { ons }\end{array}$} & \multirow{2}{*}{$\begin{array}{l}\text { Depth } \\
\text { (cm) }\end{array}$} & \multirow[t]{2}{*}{ pH } & \multirow[t]{2}{*}{$\mathrm{EC}\left(\mathbf{d S m}^{-1}\right)$} & \multirow{2}{*}{$\begin{array}{l}\mathrm{OC} \\
(\%)\end{array}$} & \multirow{2}{*}{$\begin{array}{c}\mathrm{CaCO} \\
\mathbf{3} \\
(\%)\end{array}$} & \multirow{2}{*}{$\begin{array}{c}\text { CEC } \\
(\mathbf{c m o l} \\
\left.\left(\mathbf{P}^{+}\right) \mathbf{k g}^{-1}\right)\end{array}$} & \multicolumn{4}{|c|}{$\begin{array}{l}\text { Exchangeable Cations }\left(\mathrm{cmo}\left(\mathrm{P}^{+}\right)\right. \\
\left.\mathrm{kg}^{-1}\right)\end{array}$} & \multirow[b]{2}{*}{$\begin{array}{l}\text { Sum of } \\
\text { cations }\end{array}$} & \multirow{2}{*}{$\begin{array}{l}\text { B.S. } \\
(\%)\end{array}$} \\
\hline & & & & & & & $\begin{array}{c}\mathrm{Ca}^{+} \\
+\end{array}$ & $\mathrm{Mg}^{++}$ & $\mathbf{K}^{+}$ & $\mathbf{N a}^{+}$ & & \\
\hline \multicolumn{13}{|c|}{ Pedon 1 - Shriram Mukundrao Deshmukh Babhalgaon Dist.,-Latur (Typic Haplusterts) } \\
\hline Ap & $0-18$ & 8.65 & 0.38 & 0.63 & 9.0 & 65.02 & 36.4 & 22.8 & 0.60 & 2.52 & 62.32 & 95.84 \\
\hline Bw1 & $18-36$ & 8.91 & 0.39 & 0.52 & 9.8 & 62.04 & 36.0 & 22.4 & 0.20 & 2.25 & 60.85 & 98.08 \\
\hline Bw2 & $36-53$ & 8.85 & 0.17 & 0.40 & 11.0 & 50.84 & 24.0 & 20.8 & 0.15 & 2.23 & 47.18 & 92.80 \\
\hline Bss1 & $53-66$ & 8.90 & 0.24 & 0.57 & 12.4 & 59.44 & 34.8 & 20.8 & 0.14 & 2.59 & 58.33 & 98.13 \\
\hline Bss2 & $66-82$ & 8.75 & 0.36 & 0.55 & 13.8 & 63.04 & 32.4 & 24.0 & 0.14 & 2.51 & 59.05 & 93.67 \\
\hline Bss3 & $82-150$ & 8.65 & 0.37 & 0.52 & 14.8 & 68.04 & 44.0 & 21.2 & 0.14 & 2.59 & 67.93 & 99.83 \\
\hline \multicolumn{13}{|c|}{ Pedon 2 - Nabi Ismail Pathan Babhalgaon Dist.-Latur (Typic Haplustepts) } \\
\hline Ap & $0-22$ & 8.62 & 0.20 & 0.75 & 6.8 & 62.09 & 32.0 & 22.4 & 0.16 & 1.95 & 56.51 & 91.01 \\
\hline Bw1 & $22-43$ & 8.59 & 0.21 & 0.69 & 8.8 & 64.08 & 37.2 & 24.4 & 0.13 & 2.17 & 73.90 & 99.75 \\
\hline $\mathrm{Cr}$ & $43-60$ & 8.75 & 0.21 & 0.36 & 9.6 & 55.13 & 26.0 & 14.4 & 0.09 & 2.99 & 43.48 & 78.86 \\
\hline \multicolumn{13}{|c|}{ Pedon 3 - Das Joytiram Gaykwad Babhalgaon Dist.-Latur (Typic Haplustepts) } \\
\hline Ap & $0-18$ & 8.12 & 0.17 & 0.31 & 10.8 & 63.12 & 33.6 & 21.6 & 0.40 & 2.44 & 58.04 & 91.95 \\
\hline Bw1 & $18-32$ & 8.38 & 0.19 & 0.45 & 12.4 & 59.04 & 36.4 & 19.2 & 0.34 & 2.09 & 58.03 & 98.28 \\
\hline $\mathrm{Cr}$ & $32-50$ & 8.50 & 0.15 & 0.21 & 14.2 & 50.96 & 26.8 & 12.8 & 0.16 & 1.69 & 41.45 & 81.32 \\
\hline \multicolumn{13}{|c|}{ Pedon 4 - Santosh Namdev Bhange Babhalgaon Dist.-Latur (Typic Haplustepts) } \\
\hline Ap & $0-25$ & 8.62 & 0.37 & 0.42 & 11.4 & 60.36 & 38.4 & 16.8 & 0.24 & 2.92 & 58.36 & 96.68 \\
\hline Bw1 & $25-40$ & 7.17 & 0.28 & 0.36 & 15.6 & 58.12 & 24.4 & 20.0 & 0.16 & 0.88 & 45.44 & 78.18 \\
\hline $\mathrm{Cr}$ & $40-54$ & 7.59 & 0.20 & 0.30 & 16.6 & 57.39 & 27.6 & 20.8 & 0.15 & 1.43 & 49.98 & 87.08 \\
\hline \multicolumn{13}{|c|}{ Pedon 5 - Shalik Deshmukh Babhalgaon Dist.-Latur(Typic Ustorthents) } \\
\hline Ap & $0-28$ & 7.96 & 0.18 & 0.42 & 6.4 & 32.92 & 36.2 & 15.6 & 0.12 & 0.84 & 52.76 & 95.90 \\
\hline $\mathrm{Cr}$ & $28-60$ & 8.14 & 0.21 & 0.31 & 13.6 & 34.62 & 39.8 & 17.8 & 0.19 & 1.59 & 59.38 & 94.41 \\
\hline
\end{tabular}


Table.4 Land capability classes and sub-classes of soil of Babhalgaon village (Klingebiel and Montgomery, 1961)

\begin{tabular}{|c|c|c|c|c|c|}
\hline Characteristics & $\begin{array}{c}\text { Pedon } \\
1\end{array}$ & $\begin{array}{c}\text { Pedo } \\
\text { n } 2 \\
\end{array}$ & $\begin{array}{c}\text { Pedon } \\
3\end{array}$ & $\begin{array}{c}\text { Pedon } \\
4\end{array}$ & $\begin{array}{c}\text { Pedon } \\
5\end{array}$ \\
\hline \multicolumn{6}{|l|}{ TOPOGRAPHY (t) } \\
\hline Slope $(\%)$ & I & II & II & II & II \\
\hline Erosion & I & II & III & III & III \\
\hline \multicolumn{6}{|l|}{ WETNESS (w) } \\
\hline Flooding & I & I & I & I & I \\
\hline Drainage & I & II & III & II & II \\
\hline \multicolumn{6}{|c|}{ PHYSICAL CONDITION OF SOIL (S) } \\
\hline Texture & I & II & II & II & II \\
\hline Coarse Fragments (vol. \%) & II & II & III & II & III \\
\hline Depth $(\mathbf{c m})$ & I & IV & IV & IV & VI \\
\hline \multicolumn{6}{|l|}{ FERTILITY } \\
\hline $\operatorname{CEC}\left(\mathrm{cmol} \mathrm{p}^{++} \mathrm{kg}^{-1}\right)$ & I & I & I & I & I \\
\hline Base saturation per. & I & I & I & I & I \\
\hline Organic carbon $(0-15 \mathrm{~cm})$ & III & III & IV & IV & IV \\
\hline Salinity EC ( $\left.\mathrm{dSm}^{-1}\right)$ & I & I & I & I & I \\
\hline Land capability classes & IIIs & $I V s$ & $I V s$ & $I V s$ & VIs \\
\hline
\end{tabular}

Table.5 Land irritability classification of Babhalgaon village (AIS\&LUS, 1971)

\begin{tabular}{|c|c|c|c|c|c|}
\hline Soil Properties & Pedon 1 & Pedon 2 & Pedon 3 & Pedon 4 & Pedon 5 \\
\hline Soil depth (cm) & $\mathrm{A}$ & $\mathrm{C}$ & $\mathrm{C}$ & $\mathrm{C}$ & $\mathbf{C}$ \\
\hline Slope $(\%)$ & $\mathrm{A}$ & $\mathrm{B}$ & $\mathrm{B}$ & $\mathrm{B}$ & B \\
\hline Depth of Water table & A & A & A & A & $\mathbf{A}$ \\
\hline Texture & $\mathrm{A}$ & $\mathrm{B}$ & B & B & B \\
\hline Soil Permeability (mm /hr) & A & A & A & A & $\mathbf{A}$ \\
\hline Coarse Fragments (\%) & $\mathrm{B}$ & $\mathrm{B}$ & $\mathrm{C}$ & $\mathrm{B}$ & B \\
\hline Salinity EC $\left(\mathrm{dSm}^{-1}\right)$ & A & A & A & A & A \\
\hline Salt affected area (visually in \%) & A & A & A & A & $\mathbf{A}$ \\
\hline LAND IRRIGABILITY CLASS & IIs & IIIs & IIIs & IIIs & IIIs \\
\hline
\end{tabular}


Table.6 Soil site suitability classes and yield of soybean and pigeon pea

\begin{tabular}{|c|c|c|c|c|c|c|c|c|}
\hline \multirow[t]{3}{*}{ Pedons } & \multicolumn{8}{|c|}{$\begin{array}{c}\text { Soil site suitability class (with } \\
\text { limitation) }\end{array}$} \\
\hline & \multicolumn{2}{|c|}{ NBSS and LUP (1994) } & \multicolumn{6}{|c|}{$\begin{array}{c}\text { FAO } \\
(\mathbf{1 9 8 3})\end{array}$} \\
\hline & soybean & Pigeon pea & Yield (q/ha) & $\begin{array}{c}\% \text { Yield of } \\
\text { optimum yield } \\
(22 \mathrm{q} / \mathrm{ha})\end{array}$ & litability class & $\begin{array}{l}\text { Yield } \\
(\mathrm{q} / \mathrm{ha})\end{array}$ & $\begin{array}{l}\% \text { Yield of optimum } \\
\text { yield (20q/ha) }\end{array}$ & litability class \\
\hline Pedon 1 & $\begin{array}{c}\mathrm{S} 1 \\
(\mathrm{t}, \mathrm{dr}, \mathrm{k}, \mathrm{oc}, \mathrm{p})\end{array}$ & $\begin{array}{c}\mathrm{S} 1 \\
(\mathrm{t}, \mathrm{dr}, \mathrm{k}, \mathrm{oc}, \mathrm{p})\end{array}$ & 21.3 & 96.81 & $\mathrm{~S} 1$ & 18.20 & 91.0 & S1 \\
\hline Pedon 2 & $\begin{array}{c}\mathrm{S} 2 \\
(\mathrm{~s}, \mathrm{dt}, \mathrm{t}, \mathrm{dr}, \mathrm{w}, \mathrm{k}, \mathrm{oc}, \mathrm{p})\end{array}$ & $\begin{array}{c}\mathrm{S} 2 \\
(\mathrm{~s}, \mathrm{dt}, \mathrm{t}, \mathrm{dr}, \mathrm{w}, \mathrm{k}, \mathrm{oc}, \mathrm{p})\end{array}$ & 16.9 & 76.81 & $\mathrm{~S} 2$ & 13.90 & 69.5 & S2 \\
\hline Pedon 3 & $\begin{array}{c}\mathrm{S} 2 \\
(\mathrm{~s}, \mathrm{dt}, \mathrm{t}, \mathrm{dr}, \mathrm{w}, \mathrm{k}, \mathrm{oc}, \mathrm{p})\end{array}$ & $\begin{array}{c}\mathrm{S} 2 \\
(\mathrm{~s}, \mathrm{dt}, \mathrm{e}, \mathrm{t}, \mathrm{dr}, \mathrm{w}, \mathrm{k}, \mathrm{oc}, \mathrm{p})\end{array}$ & 15.7 & 71.36 & $\mathrm{~S} 2$ & 12.70 & 63.5 & S2 \\
\hline Pedon 4 & $\begin{array}{c}\mathrm{S} 2 \\
(\mathrm{~s}, \mathrm{dt}, \mathrm{t}, \mathrm{dr}, \mathrm{w}, \mathrm{k}, \mathrm{oc}, \mathrm{p})\end{array}$ & $\begin{array}{c}\mathrm{S} 2 \\
(\mathrm{~s}, \mathrm{dt}, \mathrm{e}, \mathrm{t}, \mathrm{dr}, \mathrm{w}, \mathrm{k}, \mathrm{oc}, \mathrm{p})\end{array}$ & 15.1 & 68.63 & $\mathrm{~S} 2$ & 13.10 & 65.5 & S2 \\
\hline Pedon 5 & $\begin{array}{c}\text { S3 } \\
(\mathrm{s}, \mathrm{dt}, \mathrm{t}, \mathrm{dr}, \mathrm{w}, \mathrm{k}, \mathrm{oc}, \mathrm{p})\end{array}$ & $\begin{array}{c}\mathrm{S3} \\
(\mathrm{s}, \mathrm{dt}, \mathrm{e}, \mathrm{t}, \mathrm{dr}, \mathbf{w}, \mathbf{k}, \mathbf{o c}, \mathbf{p})\end{array}$ & 11.9 & 54.09 & S2 & 10.09 & 50.45 & S2 \\
\hline
\end{tabular}

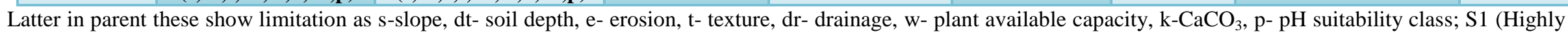
suitable), S2 (Moderately suitable), S3 (Marginally suitable), N1 (Currently not suitable), N2 (Unsuitable) 
Table.7 Soil Health Card of Babhalgaon village in Latur district

\begin{tabular}{|c|c|c|c|}
\hline \multicolumn{4}{|c|}{ Village: Babhalgaon Ta.-Latur Dist. Latur } \\
\hline & $\begin{array}{c}\text { Vertisols (Typic } \\
\text { Haplusterts) }\end{array}$ & $\begin{array}{c}\text { Inceptisols (Typic } \\
\text { Haplustepts) }\end{array}$ & Entisols (Typic Ustorthents) \\
\hline Total No.Sample & 18 & 16 & 6 \\
\hline \multicolumn{4}{|l|}{ Soil Quality } \\
\hline Soil Depth (cm) & 120 & 45 & 28 \\
\hline Texture & clay & Silty to clay & Silty clay loam \\
\hline Structure & $\begin{array}{l}\text { angular, sub-angular } \\
\text { blocky }\end{array}$ & Sub angular blocky & $\begin{array}{c}\text { Sub angular blocky to } \\
\text { granular }\end{array}$ \\
\hline PAWC (mm) & 480.40 & 107.24 & 79.0 \\
\hline Hydraulic Conductivity $\left(\mathrm{cm} \mathrm{hr}^{-1}\right)$ & 4.02 & 8.18 & 18.9 \\
\hline Coarse Fragments (\%) & 5.88 & 12.28 & 27.50 \\
\hline \multicolumn{4}{|l|}{ Biological Property } \\
\hline Fungi (CFU g $\left.{ }^{-1}\right)$ & $2.8 \times 10^{4}$ & $2.10 \times 10^{4}$ & $2.56 \times 10^{4}$ \\
\hline Actinomycetes $\left(\mathrm{CFU} \mathrm{g^{-1 }}\right)$ & $2.81 \times 10^{5}$ & $2.57 \times 10^{5}$ & $3.37 \times 10^{5}$ \\
\hline Bacteria (CFU g $\mathbf{g}^{-1}$ ) & $14.42 \times 10^{7}$ & $17.86 \times 10^{7}$ & $21.00 \times 10^{7}$ \\
\hline \multicolumn{4}{|l|}{ Nutrient Availability } \\
\hline & $\begin{array}{l}\text { Test } \\
\text { value }\end{array}$ & $\begin{array}{c}\text { Test } \\
\text { value }\end{array}$ & $\begin{array}{c}\text { Test } \\
\text { value }\end{array}$ \\
\hline
\end{tabular}




\begin{tabular}{|c|c|c|c|c|c|c|}
\hline pH & 8.39 & $\begin{array}{c}\text { Moderately } \\
\text { alkaline }\end{array}$ & 8.09 & $\begin{array}{l}\text { Moderately } \\
\text { alkaline }\end{array}$ & 8.24 & $\begin{array}{l}\text { Moderately } \\
\text { alkaline }\end{array}$ \\
\hline $\mathrm{EC}\left(\mathrm{dSm}^{-1}\right)$ & 0.28 & safe & 0.26 & safe & 0.45 & safe \\
\hline Organic Carbon (\%) & 0.53 & medium & 0.55 & medium & 0.70 & medium \\
\hline Calcium Carbonate (\%) & 10.26 & High calc. & 10.15 & High calc. & 9.53 & Mod.calc. \\
\hline Available Nitrogen (kg ha־1) & 108.01 & Low & 109.75 & Low & 129.61 & Low \\
\hline Available Phosphorus (kg ha $\left.{ }^{-1}\right)$ & 23.27 & medium & 18.76 & medium & 25.16 & high \\
\hline Available Potassium (kg ha $\left.{ }^{-1}\right)$ & 438.55 & high & 383.57 & high & 507.13 & high \\
\hline Available sulphur (mg kg-1) & 6.99 & Deficient & 7.15 & Deficient & 7.15 & Deficient \\
\hline DTPA Fe (mg kg-1) & 10.80 & Sufficient & 10.69 & Sufficient & 10.88 & Sufficient \\
\hline DTPA Mn (mg kg $\left.{ }^{-1}\right)$ & 10.05 & Sufficient & 10.72 & Sufficient & 11.70 & Sufficient \\
\hline DTPA Zn (mg kg-1) & 0.62 & Sufficient & 0.64 & Sufficient & 0.61 & Sufficient \\
\hline DTPA Cu (mg kg-1) & 2.88 & Sufficient & 2.90 & Sufficient & 2.43 & Sufficient \\
\hline $\begin{array}{l}\text { Recommendations soil site } \\
\text { suitability sustainable yield } \\
\text { 1. Selection of crop as per soil site } \\
\text { suitability. }\end{array}$ & \multicolumn{2}{|c|}{$\begin{array}{l}\text { Deep and shallow rooted } \\
\text { crop (viz } \\
\text {.pigeon pea, sugarcane and } \\
\text { soybean etc.). }\end{array}$} & \multicolumn{2}{|c|}{$\begin{array}{l}\text { Deep and shallow rooted crop } \\
\text { (viz. pigeon pea, soybean, green } \\
\text { gram, black gram). }\end{array}$} & \multicolumn{2}{|c|}{$\begin{array}{l}\text { Shallow rooted crop } \\
\text { (Viz. soybean green gram, } \\
\text { black gram). }\end{array}$} \\
\hline
\end{tabular}

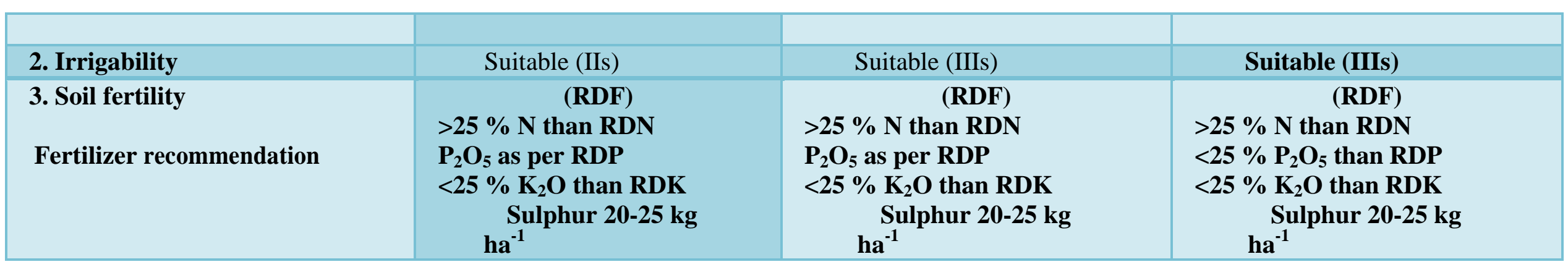


Fig
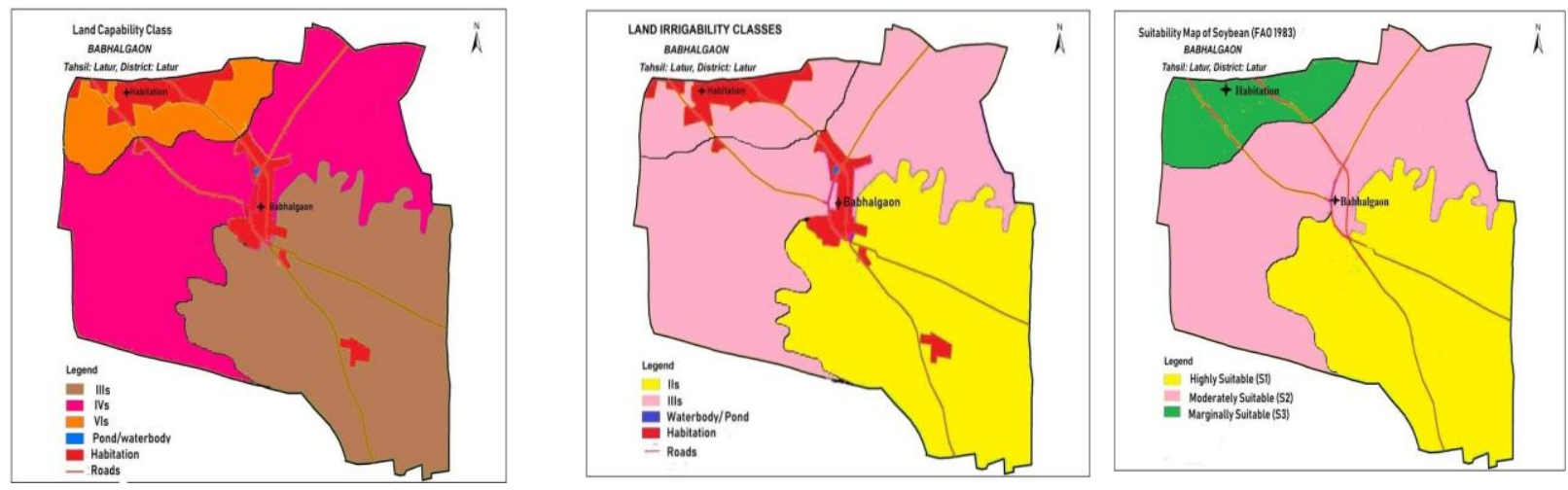

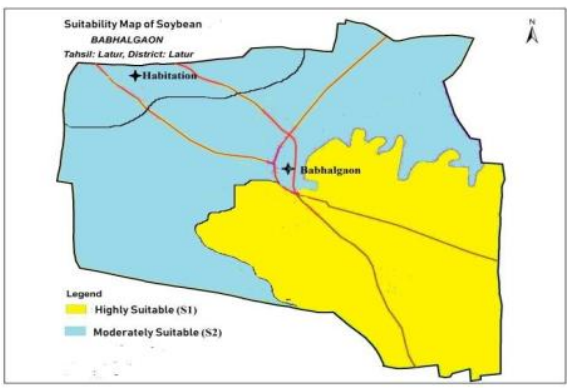

Soil - site suitability evaluation

Soil-site suitability is the fitness of given type of land for a defined use. The process of the land suitability classification is the appraisal and grouping of specific areas of land in term of their suitability and to estimate the potential of particular soil for alternative use. An intensive study of soil-site conditions in the Babhalgaon village was therefore, carried out in order to determine the suitability of some dominant crops of the area. The FAO framework on Land Evaluation (FAO, 1976) suggests a crop specific suitability system. Soybean is the most important oilseeds crop the region it is a cash crop with low cost benefit ratio. The commercially growing variety in the study area, such as PK-472, JS335, JS-330 and KL-441. The soil-site requirement given for Soybean crop (NBSS and LUP, 1994) the soils of Typic Haplustepts $\left(\mathrm{P}_{2}, \mathrm{P}_{3}\right.$ and $\left.\mathrm{P}_{4}\right)$ and Typic Ustorthents $\left(\mathrm{P}_{5}\right)$ moderately suitable (S2) and Typic Haplusterts $\left(\mathrm{P}_{1}\right)$ are highly suitable (S1) and However, according to FAO 1983 the suitability based on optimum yield (22 $\left.\mathrm{q} \mathrm{ha}^{-1}\right)$ basis the soil of Typic Haplusterts $\left(\mathrm{P}_{1}\right)$ are highly suitable ( $\mathrm{S} 1)$, Typic Haplustepts $\left(\mathrm{P}_{2}, \mathrm{P}_{3}\right.$ and $\mathrm{P}_{4}$ ) are moderately suitable (S2) and Typic Ustorthents $\left(\mathrm{P}_{5}\right)$ are marginally suitable (S3) for soybean crop. The perusal of data (Table 4.31) indicates that 333.44 ha (19.99 $\%$ of TGA) area is highly suitable (S1) and 1333.79 ha $(79.99 \%)$ area is moderately suitable (S2) for soybean cultivation.

Pigeon pea is the most important pluses crop in this area followed by soybean. The commercial variety grown in this area viz. BSMR-736, BDN-1, BDN-2. The soils of Babhalgaon village are Typic Haplustepts $\left(\mathrm{P}_{2}\right.$, $\mathrm{P}_{3}$ and $\left.\mathrm{P}_{4}\right)$ and Typic Ustorthents $\left(\mathrm{P}_{5}\right)$ are moderately suitable (S2) and Typic Haplusterts $\left(\mathrm{P}_{1}\right)$ are highly suitable (S1).

According to FAO 1983, the suitability of pigeonpea crop based on optimum yield level (20.00 qt/ha) the soils of Typic Haplusterts 
$\left(\mathrm{P}_{1}\right)$ are highly suitable (S1), Typic Haplustepts $\left(\mathrm{P}_{2}, \mathrm{P}_{3}\right.$ and $\left.\mathrm{P}_{4}\right)$ are moderately suitable $(\mathrm{S} 2)$ and Typic Ustorthents $\left(\mathrm{P}_{5}\right)$ are marginally suitable (S3) for pigeon pea crop. The perusal of data (Table 4.36) indicates that 333.44 ha (19.99\% of TGA) area is highly suitable (S1), 1333.79 ha (79.99 \% of TGA) area is moderately suitable (S2).

Soil health card is field-specific detailed report of soil fertility status and other important soil parameters that affect crop productivity. Soil health card (SHC) is a printed report that a farmer will be handed over for each of his holdings. It will contain the status of his soil with respect to 12 parameters, namely N,P,K (Macro-nutrients); $\mathrm{S}$ (Secondary- nutrient); $\mathrm{Zn}, \mathrm{Fe}, \mathrm{Cu}, \mathrm{Mn}, \mathrm{Bo}$ (Micro - nutrients) and pH, EC, OC (Physical parameters). Based on this, the SHC will also indicate fertilizer recommendations and soil amendment required for the farm. soil health and crop The SHC provide necessary information to farmers about present nutrient status of their soil/farm and recommendation for appropriate dosage of different sources of nutrient for improving production. The card, which will carry crop-wise recommendation of fertilizers required for farm lands, will help farmers identify health of soil and judiciously use soil nutrients. Farmer wise/ land parcel wise soil health card with the information consisting of slope, erosion, soil depth, colour, texture, organic carbon, $\mathrm{pH}$, electrical conductivity, macro and micro- nutrients, degradation type, etc. can guide the farmers, planners and real user.

The yield data for commonly grown crop in studied area indicated that, the yield of shallow rooted crop soybean and deep rooted crop pigeon pea under Entisols $(11.9,10.09 \mathrm{q}$ $\mathrm{ha}^{-1}$ respectively), Inceptisols $(15.9,13.23 \mathrm{q}$ $\mathrm{ha}^{-1}$ respectively) and Vertisols $(21.3,18.20 \mathrm{q}$ $\mathrm{ha}^{-1}$ respectively) and which was found 45.91, 49.55 per cent yield decrease over the optimums yield of studied area in Entisols, $27.74,33.84$ per cent yield decrease in Inceptisols, 3.19, 9.00 per cent yield decrease in Vertisols. This showed that the soil type and basic soil quality parameter Viz. texture, structure, coarse, fragment and PAWC should be consider in with existing parameter of soil health card, in addition to suggest the soil site suitability for site specific crop for sustaining the soil use and doubling the farmer income.

The information generated from remote sensing data and integrated using Geographical Information System (GIS) helps in generation of various thematic maps for crop planning, conservation and management of land resources at village level. From the above results however recommended that the Entisols (Shallow soil) soil were suitable for short duration and shallow rooted crop whereas Inceptisols and Vertisols (Moderately deep to Very Deep) soil recommended for both shallow and deep rooted crop for gating the maximum returns under suggested site specific soil management practices.

\section{References}

Ahmad, S.R. (1989). A nutritional survey report of Anab-e-shahi grapes around Hyderabad and Secunderabad. Journal South Indian Horticulture. 37 (5):262286.

AIS \& LUS (1971). Soil Survey Manual, AIS \& LUS, IARI Publication, New Delhi: $121 \mathrm{pp}$.

De La Rosa, Cardona P. and Almorza, J. (1981). Crop yield prediction based on properties of soil in Sevilla, Spain. Geoderma.25:267274.

Eswaran H. and Gathrie R.L., (1982). International technical assistance in soil survey and classification abstract. Voluntary paper 12th international congress of soil sciences. New Delhi. 
India.

FAO (1976). A Frame Work for Land Evaluation. FAO - Soils Bulletin No.32. FAO, Rome.

FAO (1983). Guidelines- Land Evaluation Irrigated Agriculture, FAO Soil Bulletin No. 55, FAO, Rome, 231p.

FAO (Food and Agriculture Organization) (1988). Salt Affected Soils and Their Management. Soil Resources, Management and Conservation Service FAO Land and Water Development Division, FAO Soils Bulletin 39, Rome, Italy.

Gardner E.A., Shaw R.J., Smith G.D. and Goughian, K.J. (1984). Plant Availability capacity concept, Measurement prediction. In Properties and Utilization of Cracking clay soils (J.W. Me Garity, E. Hoult and H.B, Co. education.) University, of new England, Armidale. 164-175.

Jersey Jackson M. L., (1979). Soil chemical analysis, Prentice Hall of India Pvt. Ltd. New Delhi, pp-545.

Klingebiel A.A. and P.H. Montgomery (1961). Land capability classification, Agriculture Handbook 210. Soil Conservation Service USDA, Washington, D.C.: 105-108.
Lindsay W.L. and Norvell, W.A. (1978). Development of DTPA soil test for Zn, $\mathrm{Fe}, \mathrm{Mn}$ and $\mathrm{Cu}$. Soil Science America Journal. 42: 421-428.

National Bureau of Soil Survey and Land use planning (1994). Proceeding - National Meet on soil-site suitability Criteria for different crops Nagpur, NBSS and LUP Publication.32p.

Piper, C.S. (1966). Soil and Plant Analysis, Hans Publishers. Bombay.

Richards L.A. (ed.) (1954). Diagnosis and improvement of saline and alkali Soils.USDA Agric.Handb.60, U. S. Govt. printing office, Washington D.C. 160. Soil Survey Staff. (2006). Key to soil taxonomy 8th edition SMSS Technical.

Subba Rao N.S. and D.Y. Gaur (1988). Microbial diversity-Management and Exploitation for Sustainable Agriculture, In: Extended Summaries International Conference on Managing Natural Resources for Sustainable Agricultural Production in the $21^{\text {st }}$ century (ed. Yadav, J.S.P. et al.),New Delhi, India. Pp.: 48-58.

Sys C. (1985). Land Evaluation Part /, 11. Ill State Univ. Ghent Publ., Belgium,

\section{How to cite this article:}

Nawkhare, A. D., P. H. Vaidya, M. K. Ghode and Titirmare, N. S. 2020. Assessment of Soil Quality of Babhalgaon Village of Latur District for Soil Health and Land Resource Management by using Remote Sensing and GIS Techniques. Int.J.Curr.Microbiol.App.Sci. 9(07): 4009-4023. doi: https://doi.org/10.20546/ijcmas.2020.907.471 